\title{
Identification Factors Affecting Variation and Change Order of Design-Build Projects
}

\author{
Phong Thanh Nguyen ${ }^{1} \&$ Hanh Thi Hong Nguyen ${ }^{2}$ \\ ${ }^{1}$ Department of Project Management, Ho Chi Minh City Open University, Ho Chi Minh City, Vietnam \\ ${ }^{2}$ Faculty of Accounting and Auditing, Ho Chi Minh City Open University, Ho Chi Minh City, Vietnam \\ Correspondence: Phong Thanh Nguyen, Department of Project Management, Ho Chi Minh City Open University, Ho \\ Chi Minh City, Vietnam. E-mail: phong.nt@ou.edu.vn
}

Received: December 24, 2019

Accepted: February 7, 2020

Online Published: June 16, 2020

doi:10.5430/rwe.v11n3p59

URL: https://doi.org/10.5430/rwe.v11n3p59

\begin{abstract}
Variations and change orders are inevitable in the course of implementing a construction investment project. It can appear throughout the project from the design phase to the construction, acceptance, and completion of the project. This change affects more or less the schedule, quality, and cost of the project. On the other hand, variations and changes orders may also cause disputes and conflicts among project stakeholders. In order to overcome this issue, this paper presents critical the factors which need to be addressed and used for change orders in design-build projects in Vietnam. The results showed that written instructions, variation value, and scope of variation are the three most important factors used in the variation management process in design-build projects in Vietnam.
\end{abstract}

Keywords: building information modeling, change order, design-build, project management

\section{Introduction}

The construction industry plays a crucial role in the national economy in developing countries such as Vietnam (Anaman \& Egyir, 2019; Huynh et al., 2018; Kasuma et al., 2019; Likhitruangsilp \& Ioannou, 2004; Quyen, Phong, \& Vy, 2017; Nguyen et al., 2016). According to Business Monitor International's forecast, the civil and industrial construction industry in Vietnam has been estimated to grow at an average rate of 6.6\% per year from 2017 to 2025 (Ha \& Lam, 2017; Ha \& Nguyen, 2014; Ha \& Tam, 2015; H. M. Nguyen, 2018; Thanh \& Ha, 2013). Vietnamese economy grows stably, sustainably, and the urbanization rate is improved and expected for a substantial increase in the future (Do et al., 2016; Nguyen, 2018; Nguyen, Bui, \& Vo, 2019; Nguyen, Bui, Vo, \& McAleer, 2019; Nguyen \& Quyen, 2017; Vo et al., 2019). The amendments and supplements to the Vietnam's Law and related laws and policies on supporting demand stimulus contribute to the warming of the real estate market up has led to the growth of civil construction and industry segments (Nguyen, Nguyen, Ngo, \& Nguyen, 2019; Nguyen, 2011; Nguyen, Likhitruangsilp, \& Onishi, 2017; To et al., 2019).

In order for the construction industry to effectively take advantage of opportunities in the coming years, one of the difficulties to be faced is the project change management process in construction, especially projects implemented in the form of design-build contracts (Huynh et al., 2018; Likhitruangsilp et al., 2018; Vo et al., 2019). Owners often have difficulties in making the cost estimate for a project during the contractor selection period when there are no detailed design documents since the design is undertaken by a separate contractor, the design-build contractor. The design-build contractor also faces high risks in meeting the requirements of the owners because they fail to accurately estimate the construction volume to be performed (Nguyen \& Nguyen, 2020). This leads inevitably to many changes arising in the process of project implementation. As a result, these changes affect the schedule, quality, and cost of the construction project. Therefore, this paper presents essential factors to be used in variation and change orders for design-build projects in Vietnam.

\section{Research Background}

In the design-build approach, the main contractor is responsible to the owner for all the design documents and directly executes all the work of an investment project to ensure the project quality, schedule, cost, and other specific requirements of the owner are met. There are many advantages of design-build projects for a contractor, including:

(i) Fully promoting the active, flexible, and creative role of contractors in the technical solutions of the design, and project management. The main contractor can take advantage of the subcontractors' technical skills and management 
experience when implementing the project (Nguyen et al., 2015).

(ii) Limiting manpower or human resource costs and expenses. Limiting the inadequacies in operation between owner, design unit, equipment supply firm and construction contractor, etc. (Ha, 2013; Nguyen et al., 2018; Nguyen et al., 2019; Nguyen et al., 2017). The contractor shortens the process of acceptance of the work volume and quality to facilitate the advance and payments of money according to each construction stage or work package;

(iii) Shortening the project implementation duration because the contractor is more active in all stages of the implementation process. This creates good cooperation with the owner and the supervision consultancy unit of the owner during project implementation. Because the construction contractor has the project from the beginning, the time for the contractor to get familiar with the design, propose design adjustments in accordance with the construction method, or propose to adjust the construction method following the design is reduced (Long, Tran, \& Nguyen, 2019; Luong, Tran, \& Nguyen, 2018; Nguyen et al., 2018). In addition, the schedule of the project can be accelerated, even when the design is not complete.

(iv) The economic efficiency brought to the business is more significant due to the activeness in design, the technical proposal, which saves material costs, labor, and project implementation time (Diem \& Ha, 2013; Ha, 2017; Ha \& An, 2015; Ha, Le, \& Trung-Kien, 2019; Ha \& Luan, 2018; Nguyen \& Khoa, 2019; Nguyen, Tran, \& Huynh, 2019; Nguyen \& Quyen, 2017).

Although the design-build project may bring benefits for the construction contractor, there are still many potential variations and change orders during project execution that need to be considered carefully by a project manager. Based on journal papers and in-depth interviews with nine experienced experts, the authors propose the following factors affecting variation and change orders in design-build projects in Vietnam in Table 1:

Table 1. Factors in variation and change order of design-build projects

\begin{tabular}{|c|c|c|}
\hline \multirow{2}{*}{\multicolumn{2}{|c|}{$\begin{array}{c}\text { Factors } \\
\text { Specifications } \\
\end{array}$}} & \multirow[t]{2}{*}{ Meaning } \\
\hline & & \\
\hline T1 & Specification & $\begin{array}{l}\text { Specification plays an important role and is the basis for acceptance } \\
\text { of the construction items and variations }\end{array}$ \\
\hline \multirow[t]{2}{*}{$\mathrm{T} 2$} & $\begin{array}{l}\text { Design drawing } \\
\text { change }\end{array}$ & $\begin{array}{l}\text { Shop drawings approved on changes is the legal basis for variation } \\
\text { and change order implementation }\end{array}$ \\
\hline & Contract & \\
\hline $\mathrm{C} 1$ & Scope of contract & $\begin{array}{l}\text { The scope of a contract is a request for the scope of performance } \\
\text { under the agreement between the parties at the beginning of the } \\
\text { project }\end{array}$ \\
\hline \multirow[t]{2}{*}{$\mathrm{C} 2$} & Variation and change order value & The new value outside the official contract. \\
\hline & Information & \\
\hline I1 & Request for information (RFIs) & $\begin{array}{l}\text { These are the written requests for clarification of design information } \\
\text { variation before construction }\end{array}$ \\
\hline $\mathrm{I} 2$ & Official letters & $\begin{array}{l}\text { These are documents in the form of confirmation, request, and } \\
\text { response from the parties about variations }\end{array}$ \\
\hline I3 & Minutes of Memory & $\begin{array}{l}\text { These are minutes recording the variation information during the } \\
\text { construction process. It is recorded in briefings. }\end{array}$ \\
\hline I4 & Site memory & $\begin{array}{l}\text { These are minutes recording the variation information during the } \\
\text { construction process. It is recorded directly at the construction site. }\end{array}$ \\
\hline I5 & Written instruction & $\begin{array}{l}\text { This is the documentation sending an official request to the } \\
\text { contractor from the owner, which is the legal basis for variation } \\
\text { implementation }\end{array}$ \\
\hline I6 & Oral instruction & $\begin{array}{l}\text { This is a request to the contractor from the owner as a legal basis for } \\
\text { variation implementation. It is valid within } 24 \text { hours and requires a } \\
\text { written instruction to store it. }\end{array}$ \\
\hline I7 & Variation and change order email & $\begin{array}{l}\text { It is the document sending an official request to the contractor from } \\
\text { the owner, which a legal basis for variation and change order } \\
\text { implementation by using email. }\end{array}$ \\
\hline
\end{tabular}




\section{Research Methods and Results}

The survey respondents were individuals who had wide experience in working for the main contractors and had been involved in civil and industrial construction projects using the design-build approach. After collection, any questionnaires in which interviewees did not understand variation management will be removed. After nearly two months of collecting data, there are twenty-seven valid questionnaires. Of these, six people were senior leaders $(22 \%)$, three people were project directors (11\%), three people project site managers or deputy site managers (11\%), two people were chief supervisors (7\%), two people were the senior managers of the investor (7\%), two were team leaders of the consultant (7\%), and nine people were members of the project management unit (33\%). The survey findings in figure 1 show that not all information used daily is considered an important factor in variation procedure and management. Some factors, variation emails, site memory, letters of notification, and requests for information (RFIs) are rarely used (accounting for less than $41 \%$ of the survey results). However, there were some factors frequently used in the variation and change order process, such as written instructions, variation value, and the scope of the contract.

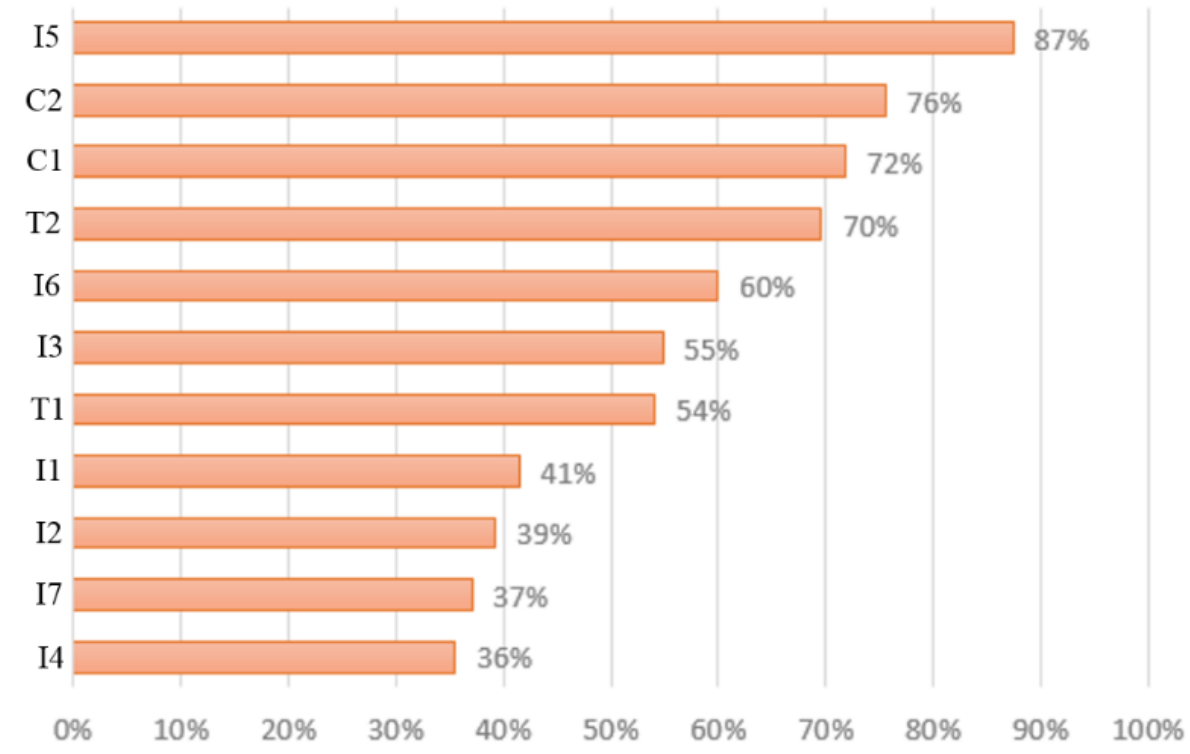

Figure 1. Ranking factors in variation and change order of design-build projects

\section{Discussion}

\subsection{Written Instruction}

Due to the unique and complex characteristics of construction projects, the supervision of quality, cost, scope, and schedule of projects is carried out during the construction process from the commencement to completion, acceptance, and put into use (Phong Thanh Nguyen et al., 2018; Pham, Dao, Cho, Nguyen, \& Pham-Hang, 2019). It involves a large number of tasks, human resource requirements, and a wide range of specializations. This results in massive amounts of information and documents prepared and exchanged in the construction project even for small-scale projects (Bahrami et al., 2019; Chassiakos \& Sakellaropoulos, 2008). On the other hand, in the actual construction process, there are many problems such as design changes, personnel changes, changes in materials used, etc. These changes caused difficulties later in the preparation, management, and completion of variation records and payment of works. Also, this made synchronizing information difficult throughout the project. The consequence is that the construction work may not be synchronized with the design work. Not to mention that all companies operate through specialized departments, so information is required to be disseminated through the departments for understanding, extending the variation duration. Therefore, the issued changes or variations in the project life cycle needed to be expressed in writing, or the dossiers of quality management, acceptance, and completion must be clear and coherent. These documents were vital for the success of construction projects. High-quality management records are the primary condition for a good quality construction process (Mena et al., 2010; Nguyen et al., 2017). 


\subsection{Variation Value}

The scope of a contract is a request for the scope of performance under the agreement between the parties at the beginning. Variation value is the new value outside the scope of the official contract. In construction projects, project managers always face variations that can appear from the preliminary design phase to the construction phase; however, in fact, most of the changes are likely to occur during the construction phase (Lee, 2008; Nguyen \& Likhitruangsilp, 2017). They are the source of increasing project costs and time. Also, they can cause disputes and weaken project stakeholder relationships. Therefore, project managers must make every effort to find the best solution for the change to ensure the basic objectives of the project of cost, time, and quality (Luong et al., 2018; Shourangiz et al., 2011).

Variations and change orders come for many reasons. They may arise due to the owner's request or due to differences between the initial design drawings and specifications. In general, Keane, Sertyesilisik, and Ross Andrew (2010) has categorized all the reasons for the variations into the following four groups:

(i) Because owners decide to change the scope of work due to financial problems and misconceptions about the final product, and potential

(ii) Due to the differences between the drawings and the real construction site;

(iii) Due to inefficiency of the contractor in planning leading machinery and materials, and financial difficulties;

(iv) Changes due to unforeseen problems.

When disputes and lawsuits occur between project stakeholders due to variations, documents, and construction dossiers may be used as evidence in court (Yousefi, Hipel, \& Hegazy, 2010). Therefore, these documents are recorded for quick search. A quality dossier should be brief, clear, consistent, and complete. In addition, it also serves as an accurate basis for timely, efficient settlement and for improving the performance and working quality of employees in the project. Documents and records are the basis of all reliable and information structures for all project participants to quickly access and update the project information (Qodim et al., 2019; Ramakrishnan et al., 2020). Proper documentation increases communication, reduces errors and misunderstandings, and increases the decision-making time for the project manager. Therefore, it saves time and costs as well as potentially improving the quality of construction.

Due to the importance and complexity of the preparation and management of variation records, construction staff who prepare and manage records or staff in charge of acceptance are required to carry out fully and properly the procedures throughout the lifespan of the project. Since then, it is sufficient documents to claim the volume at the payment phase of the project. In fact, this process of document collection causes many difficulties for contractors who seek to explain the scope of variation because the ability to store information is often limited and errors are frequent due to a large amount of information (Ayshwarya et al., 2019; Suyatno et al., 2019; Wiendara et al., 2019). Moreover, it is also due to the many departments that must handle the implementation process for carrying out the variation.

The stage from the beginning of the variation and change order to the stage of issuing the official site instruction from the owner or consultant in the design-build projects in Vietnam takes, on average, 5-10 days because project drawings are not specific and detailed. Requests for information (RFIs) will be high according to each variation order, which is deployed at the beginning of the project. Each request for information response is an updated basis for detailed construction shop drawing drawings. If the management of shop drawing versions is not strict and logical, it will cause misunderstandings in the construction work, leading to disputes between contractors and owners. This may also cause disputes between the site quantity surveyor and the owner later when making a volume payment.

\subsection{Change of Design Drawings}

Design changes are defined as changes due to modifications within or beyond the original scope of work. It may require a redesign and modification of contract documents. The reason for the appearance of changes in design drawings often is due to inadequate details, misunderstandings, and incompetence in the preparation of the set of detailed drawings. In fact, the complicated management process results in many versions of detailed drawings. It confuses the implementation, which leads to supplies becoming out of control, extending the project duration and costs. This also affects the process of preparing the project completion drawings. The details which are not updated during the project implementation will make great difficulty for the project operation and maintenance later.

\section{Conclusion}

The amount of information transferred from the design to the construction phases of a project is enormous, so there is a need for more useful information management processes and methods. However, not all of this information is fully updated, accurate, and useful in the variation management of design-build projects. The research results showed that 
written instructions, variation value, and scope of variation are the three most important types of information used in the variation management process in design-build projects in Vietnam. Identification of these essential factors will help project managers gain a deeper understanding of some aspects of the information transfer process and information technology application status to build IT application processes into the variation management of the project. Several benefits for the variation management will result, such as reducing the time of implementation, updating the data for the whole system in a centralized way, planning the arrangement of personnel and support in decision-making to adjust smoothly, quickly the material preparation, supporting quick payment, reducing the risk of improper construction, and improving customer satisfaction (Thalhah, Tohir, Nguyen, Shankar, \& Rahim, 2019).

\section{Acknowledgments}

The authors gratefully acknowledge Ho Chi Minh City Open University, Vietnam, for supporting this research. We also acknowledge Dr. Thu Anh Nguyen, BIM Lab Director, Ho Chi Minh City University of Technology (HCMUT), VNU-HCM for helping this research.

\section{References}

Anaman, K. A., \& Egyir, I. S. (2019). Economic shocks and the growth of the construction industry in Ghana over the 50-year period from 1968 to 2017. Research in World Economy, 10(1), 1-16. https://doi.org/10.5430/rwe.v10n1p1

Ayshwarya, B., Nguyen, P. T., Alismi, Abadi, S., Shankar, K., Hashim, W., Maseleno, A. (2019). Design analysis of web-based furniture marketing information system. International Journal of Recent Technology and Engineering, 8(2 Special Issue 3), 1513-1519. https://doi.org/10.35940/ijrte.B1277.0782S319

Bahrami, N., Liu, S., Ponkratov, V. V., Nguyen, P. T., Maseleno, A., \& Berti, S. (2019). Novel load management for renewable generation sources/battery system through cut energy expenditure and generate revenue. International Journal of Ambient Energy. https://doi.org/10.1080/01430750.2019.1636868

Chassiakos, A., \& Sakellaropoulos, S. (2008). A web-based system for managing construction information. Advances in Engineering Software, 39(11), 865-876.

Diem, P. T., \& Ha, N. M. (2013). Analysing the Employment Status of Graduate Students: The Case of Kent International College in Vietnam. Advances in Management and Applied Economics, 3(4), 235.

Do, T. S., Veerasak, L., Masamitsu, O., \& Phong, T. N. (2016). Different perceptions of concern factors for strategic investment of the private sector in public - private partnership transportation projects. ASEAN Engineering Journal, 5(2), 05-25.

Ha, N. M. (2013). The effect of firm's growth on firm survival in Vietnam. International Business Research, 6(5), 142.

Ha, N. M. (2017). Impact of capital structure and cash holdings on firm value: case of firms listed on the Ho Chi Minh Stock Exchange. International Journal of Economics and Financial Issues, 7(1), 24-30.

Ha, N. M., \& An, N. T. (2015). Impact of Work-Family Conflict on Job Performance of Nurses Working for Hopitals In Ho Chi Minh City. Journal Of Science Ho Chi Minh City Open University, (4), 16.

Ha, N. M., \& Lam, N. H. (2017). The effects of celebrity endorsement on customer's attitude toward brand and purchase intention. International Journal of Economics and Finance, 9(1), 64-77.

Ha, N. M., Le, N. D., \& Trung-Kien, P. (2019). The impact of urbanization on income inequality: A study in Vietnam. Journal of Risk and Financial Management, 12(3), 146.

Ha, N. M., \& Luan, N. V. (2018). The Effect Of Employers'attraction And Social Media On Job Application Attention of Senior Students At Pharmaceutical Universities In Vietnam. International Journal of Business and Society, 19(2).

Ha, N. M., \& Nguyen, T. V. H. (2014). The influence of leadership behaviors on employee performance in the context of software companies in Vietnam. Advances in Management and Applied Economics, 4(3), 157.

Ha, N. M., \& Tam, H. L. (2015). Attitudes and purchase intention towards counterfeiting luxurious fashion products in Vietnam. International Journal of Economics and Finance, 7(11), 207-221.

Huynh, V. D. B., Nguyen, P. V., Nguyen, Q. L. H. T. T., \& Nguyen, P. T. (2018). Application of Fuzzy Analytical Hierarchy Process based on Geometric Mean Method to Prioritize Social Capital Network Indicators. International Journal of Advanced Computer Science and Applications, 9(12), 182-186. 
Huynh, V. D. B., Nguyen, Q. L. H. T. T., Van Nguyen, P., \& Nguyen, P. T. (2018). Application Partial Least Square Structural Equation To Develop A Job Search Success Measurement Model. Journal of Mechanics of Continua and Mathematical Sciences, 13(5).

Kasuma, J., Ismailly, N., Ghaffari, S., Rusuli, M. S. C., \& Gapor, A. H. A. (2019). Environmental factor, education \&amp; training and PPE impact on safety performance: A study among construction workers at SESCO Sub-Station, Balingian, Sarawak. Research in World Economy, 10(2 Special Issue), 38-47. https://doi.org/10.5430/rwe.v10n2p38

Keane, P., Sertyesilisik, B., \& Ross Andrew, D. (2010). Variations and Change Orders on Construction Projects. Journal of Legal Affairs and Dispute Resolution in Engineering and Construction, 2(2), 89-96. https://doi.org/10.1061/(ASCE)LA.1943-4170.0000016

Lee, J.-K. (2008). Cost overrun and cause in Korean social overhead capital projects: Roads, rails, airports, and ports. Journal of Urban Planning and Development, 134(2), 59-62.

Likhitruangsilp, V., Handayani Tantri, N., Ioannou Photios, G., \& Yabuki, N. (2018). A BIM-Enabled System for Evaluating Impacts of Construction Change Orders. In Construction Research Congress 2018 (pp. 622-631).

Likhitruangsilp, V., \& Ioannou, P. G. (2004). Detailed probabilistic construction estimating by Monte Carlo simulation. Paper presented at the Proceedings of the 9th National Convention on Civil Engineering 2004.

Long, L. D., Tran, D. H., \& Nguyen, P. T. (2019). Hybrid multiple objective evolutionary algorithms for optimising multi-mode time, cost and risk trade-off problem. International Journal of Computer Applications in Technology, 60(3), 203-214. https://doi.org/10.1504/IJCAT.2019.100299

Luong, D.-L., Tran, D.-H., \& Nguyen, P. T. (2018). Optimizing multi-mode time-cost-quality trade-off of construction project using opposition multiple objective difference evolution. International Journal of Construction Management, 01-13.

Mena, Á., López, F., Framiñan, J. M., Flores, F., \& Gallego, J. M. (2010). XPDRL project: Improving the project documentation quality in the Spanish architectural, engineering and construction sector. Automation in Construction, 19(2), 270-282.

Nguyen, H. M. (2018). The relationship between urbanization and economic growth. International Journal of Social Economics.

Nguyen, H. M., Bui, N. H., \& Vo, D. H. (2019). The Nexus between Economic Integration and Growth: Application to Vietnam. Annals of Financial Economics, 14(03), 1950014.

Nguyen, H. M., Bui, N. H., Vo, D. H., \& McAleer, M. (2019). Energy consumption and economic growth: Evidence from Vietnam. Journal of Reviews on Global Economics, 8, 350-361.

Nguyen, H. M., \& Khoa, B. T. (2019a). The Relationship between the Perceived Mental Benefits, Online Trust, and Personal Information Disclosure in Online Shopping. The Journal of Asian Finance, Economics and Business (JAFEB), 6, 261-270.

Nguyen, H. M., \& Khoa, B. T. (2019b). A Study on the Chain of Cost Values-Online Trust: Applications in Mobile Commerce in Vietnam. Journal of Applied Economic Sciences, 14(1).

Nguyen, H. M., Nguyen, C., Ngo, T. T., \& Nguyen, L. V. (2019). The effects of job crafting on work engagement and work performance: A study of vietnamese commercial banks. The Journal of Asian Finance, Economics and Business (JAFEB), 6(2), 189-201.

Nguyen, M. (2011). Determinants of Firm Growth in Employment in Vietnam. TMC Academic Journal, 5(2), 34-50.

Nguyen, M. H., \& Khoa, B. T. (2019a). Customer Electronic Loyalty towards Online Business: The role of Online Trust, Perceived Mental Benefits and Hedonic Value. The Journal of Distribution Science, 17, 81-93.

Nguyen, M. H., \& Khoa, B. T. (2019b). Perceived Mental Benefit in Electronic Commerce: Development and Validation. Sustainability, 11(23), 6587.

Nguyen, M. H., Tran, B. T., \& Huynh, L. T. (2019). Relation Between Employees and Customers Affects to the Positive Word of Mouth Through Customer Satisfaction. The Journal of Distribution Science, 17(6), 65-75.

Nguyen, P., \& Nguyen, P. (2020). Risk Management in Engineering and Construction: A Case Study in Design-Build Projects in Vietnam. Engineering, Technology \& Applied Science Research, 10(1), 5237-5241. 
Nguyen, P. T., \& Likhitruangsilp, V. (2017). Identification risk factors affecting concession period length for public-private partnership infrastructure projects. International Journal of Civil Engineering and Technology, 8(6), 342-348.

Nguyen, P. T., Nguyen, T. A., Cao, T. M., Vo, K. D., Huynh, V. D. B., Nguyen, Q. L. H. T. T., , . Le, L. P. (2018). Construction Project Quality Management using Building Information Modeling 360 Field. International Journal of Advanced Computer Science and Applications, 9(10), 228-233.

Nguyen, P. T., Nguyen, T. A., Ha, N. T. H., \& Nguyen, T. N. (2017). Facilities management in high rise buildings using building information modeling. International Journal of Advanced and Applied Sciences, 4(2), 1-9. https://doi.org/10.21833/ijaas.2017.02.001

Nguyen, P. T., Nguyen, T. A., Nguyen, Q., Huynh, V. D. B., \& Vo, K. D. (2018). Ranking project success criteria in power engineering companies using fuzzy decision-making method. International Journal of Advanced and Applied Sciences, 5(8), 91-94. https://doi.org/10.21833/ijaas.2018.08.011

Nguyen, P. T., Nguyen, V. N., Pham, L. H., Nguyen, T. A., Nguyen, Q., \& Huynh, V. D. B. (2018). Application of supply chain management in construction industry. Advances in Science and Technology-Research Journal, 12(2), 11-19. https://doi.org/10.12913/22998624/92112

Nguyen, P. T., Vu, N. B., Van Nguyen, L., Le, L. P., \& Vo, K. D. (2019). The Application of Fuzzy Analytic Hierarchy Process (F-AHP) in Engineering Project Management. Paper presented at the 2018 IEEE 5th International Conference on Engineering Technologies and Applied Sciences, ICETAS 2018.

Nguyen, T. A., \& Nguyen, P. T. (2015). Explaining model for supervisor's behavior on safety action based on their perceptions. ARPN Journal of Engineering and Applied Sciences, 10(20), 9562-9572.

Pham, H. C., Dao, N.-N., Cho, S., Nguyen, P. T., \& Pham-Hang, A.-T. (2019). Construction Hazard Investigation Leveraging Object Anatomization on an Augmented Photoreality Platform. Applied Sciences, 9(21), 4477.

Phong, N. T., Likhitruangsilp, V., \& Onishi, M. (2017). Developing a stochastic traffic volume prediction model for public-private partnership projects. Paper presented at the AIP Conference Proceedings.

Phong, N. T., Phuc, V. N., \& Quyen, T. T. H. L. N. (2017). Application of Fuzzy Analytic Network Process and TOPSIS Method for Material Supplier Selection. Key Engineering Materials, 728, 411-415.

Phong, N. T., \& Quyen, N. L. H. T. T. (2017). Application fuzzy multi-attribute decision analysis method to prioritize project success criteria. AIP Conference Proceedings, 1903(1), 111-116. https://doi.org/10.1063/1.5011580

Qodim, H., Herningsih, Nguyen, P. T., Nguyen, Q. L. H. T. T., \& Toding, A. (2019). Educating the information integration using contextual knowledge and ontology merging in advanced levels. International Journal of Higher Education, 8(8), 24-29. https://doi.org/10.5430/ijhe.v8n8p24

Quyen, N. L. H. T. T., Phong, T. N., \& Vy, D. B. H. (2017). A hybrid multi criteria decision analysis for engineering project manager evaluation. International Journal of Advanced and Applied Sciences, 4(4), 49-52.

Ramakrishnan, J., Shabbir, M. S., Kassim, N. M., Nguyen, P. T., \& Mavaluru, D. (2020). A comprehensive and systematic review of the network virtualization techniques in the IoT. International Journal of Communication Systems, $n / a($ n/a), e4331. https://doi.org/10.1002/dac.4331

Shourangiz, E., Mohamad, M. I., Hassanabadi, M. S., Banihashemi, S., Bakhtiari, M., \& Torabi, M. (2011). Flexibility of BIM towards design change. International Proceedings of Economics Development \& Research, 15(2), 79-83.

Suyatno, Nguyen, P. T., Dinesh Kumar, A., Pandi Selvam, R., \& Shankar, K. (2019). Examination of information system design for student's scoring processing. International Journal of Engineering and Advanced Technology, 8(6 Special Issue 2), 1143-1147. https://doi.org/10.35940/ijeat.F1312.0886S219

Thalhah, S. Z., Tohir, M., Nguyen, P. T., Shankar, K., \& Rahim, R. (2019). Mathematical issues in data science and applications for health care. International Journal of Recent Technology and Engineering, 8(2 Special Issue 11), 4153-4156. https://doi.org/10.35940/ijrte.B1599.0982S1119

Thanh, V. H., \& Ha, N. M. (2013). The effect of Banking relationship on firm performance in Vietnam. International Journal of Economics and Finance, 5(5), 148-158.

To, A. H., Ha, D. T.-T., Nguyen, H. M., \& Vo, D. H. (2019). The impact of foreign direct investment on environment degradation: Evidence from emerging markets in Asia. International journal of Environmental Research and 
Public Health, 16(9), 1636.

Van Nguyen, P., Nguyen, P. T., Thuy, Q. L. H., Nguyen, T., \& Huynh, V. D. B. (2016). Calculating Weights of Social Capital Index Using Analytic Hierarchy Process. International Journal of Economics and Financial Issues, 6(3), 1189-1193.

Vo, D. H., Van Nguyen, P., Nguyen, H. M., Vo, A. T., \& Nguyen, T. C. (2019). Derivatives market and economic growth nexus: Policy implications for emerging markets. The North American Journal of Economics and Finance, 100866.

Vo, K. D., Nguyen, P. T., Pham, C. P., Huynh, V. D. B., Nguyen, Q. L. H. T. T., Vu, N. B., \& Le, L. P. (2019). Measuring individual job performance of project managers using fuzzy extended analytic method. International Journal of Recent Technology and Engineering, $8(2$ Special Issue), 86-90. https://doi.org/10.35940/ijrte.a1379.078219

Wiendara, G. C., Abadi, S., Ilayaraja, M., Shankar, K., Nguyen, P. T., Hashim, W., \& Maseleno, A. (2019). Multi user-based patient service information system in public health center. International Journal of Engineering and Advanced Technology, 8(6 Special Issue 2), 1034-1039. https://doi.org/10.35940/ijeat.F1315.0886S219

Yousefi, S., Hipel, K. W., \& Hegazy, T. (2010). Attitude-based negotiation methodology for the management of construction disputes. Journal of Management in Engineering, 26(3), 114-122. 